\title{
CARDIO-RESPIRATORY INTEGRATION IN DIVING BULLFROG Lithobates catesbeianus (Shaw, 1802)
}

\author{
FERNANDES, Marcelo dos Santos ${ }^{1}$ \\ GLASS, Mogens Less ${ }^{2}$
}

Recebido em: 2010-10-26

Aprovado em: 2011-10-24

ISSUE DOI: $10.3738 / 1982.2278 .500$

\begin{abstract}
SUMMARY: Cardiac frequency and blood pressure were measured during voluntary diving in the bullfrog, Lithobates catesbeianus, exposed to $15^{\circ} \mathrm{C}$ or, alternatively, $25^{\circ} \mathrm{C}$. Diving caused bradycardia and reduction of blood pressure. Cardiac frequency was $27.1 \pm 2.2$ for breath periods and $19.3 \pm 2.7$ for diving periods at $15^{\circ} \mathrm{C}$, and $47.7 \pm 4.4$ and $35.3 \pm 3.6$ for $25^{\circ} \mathrm{C}$. Systolic blood pressure was $39,6 \pm 0,9$ for breath periods and $36,2 \pm 0,4$ for diving periods at $15^{\circ} \mathrm{C}$, and $42,4 \pm 1,0$ and $39,8 \pm 0,5$ at $25^{\circ} \mathrm{C}$. Diastolic blood pressure was $32,3 \pm 0,6$ for breath periods and $29,5 \pm 0,5$ for diving periods at $15^{\circ} \mathrm{C}$, and $35,3 \pm 0,9$ and $33,2 \pm 0,6$ at $25^{\circ} \mathrm{C}$. The animal was artificially ventilated during diving with normoxic, hypoxic $\left(5 \% \mathrm{O}_{2}\right)$ and hypercarbic gas mixtures $\left(6 \% \mathrm{CO}_{2}\right)$. None of these procedures produced any change of blood pressure or cardiac frequency. Cardio-vascular effects have, however, been reported in some other studies on amphibians. As a new aspect, we applied artificial ventilation during a voluntary dive in the frog. Surfacing, elicited tachycardia and elevated blood pressure, These cardiovascular reflexes depend on a stimulus that still needs to be identified.
\end{abstract}

Keywords: Bullfrog. Diving. Bradycardia. Arterial blood pressure. Artificial ventilation. Gas mixtures.

RESUMO: A freqüência cardíaca e a pressão arterial foram medidas durante o mergulho voluntário na rã Lithobates catesbeianus, exposto a $15^{\circ} \mathrm{C}$ ou, alternativamente, a $25^{\circ} \mathrm{C}$. O mergulho causou a bradicardia e redução da pressão arterial. A frequencia cardíaca foi $27.1 \pm 2.2$ para períodos respiratórios e $19.3 \pm 2.7$ para os periodo de mergulho à $15^{\circ} \mathrm{C}$, and $47.7 \pm 4.4$ e $35.3 \pm 3.6$ à $25^{\circ} \mathrm{C}$. A pressão arterial sistólica foi $39,6 \pm 0,9$ para os periodos respiratórios e $36,2 \pm 0,4$ para periods de mergulho à $15^{\circ} \mathrm{C}$, e $42,4 \pm 1,0$ e $39,8 \pm 0,5$ à $25^{\circ} \mathrm{C}$. A pressão diastólica foi 32,3 $\pm 0,6$ para periodos respiratórios e $29,5 \pm 0,5$ para periodos de mergulho à $15^{\circ} \mathrm{C}$, e $35,3 \pm 0,9$ e $33,2 \pm 0,6$ à $25^{\circ} \mathrm{C}$. $\mathrm{O}$ animal foi utilizado para ventilação artificial durante o mergulho com normóxia, hipóxia $\left(5 \%\right.$ de $\left.\mathrm{O}_{2}\right)$ e misturas de gases hipercárbica $\left(6 \%\right.$ de $\left.\mathrm{CO}_{2}\right)$. Nenhum desses procedimentos produziu qualquer alteração da pressão arterial ou frequiência cardíaca. Os efeitos cardio-vasculares, no entanto, têm sido relatado em alguns outros estudos sobre os anfíbios. Como um novo aspecto, foi aplicado a ventilação artificial durante um mergulho voluntário no sapo. $\mathrm{O}$ ato de toca a superficie resultou em taquicardia e aumento da pressão arterial. Estes reflexos cardiovasculares dependem de um estímulo que ainda precisa ser identificado.

Palavras-chave: Rã-touro. Mergulho. Bradicardia. Pressão arterial. Ventilação artificial. Mistura de gás.

\section{INTRODUCTION}

Amphibians develop bradycardia when submersed, and the return to the surface is accompanied by tachycardia (ANDERSEN 1966; JOHANSEN, 1966). This coupling of cardiac frequency to ventilation has been reported for forced and voluntaries dives ( JONES

\footnotetext{
${ }^{1}$ Department of Zoophysiology, Educational Foundation of Ituverava. Cel. Flauzino Barbosa Sandoval Street, 1259, 14500-000 Ituverava, São Paulo. Brazil.. Corresponding author: e-mail, enzopipapipa @ yahoo.com.br 2. Department of Physiology, Faculty of Medicine of Ribeirão Preto, University of São Paulo, Bandeirantes Avenue 3900, 14.049-900 Ribeirão Preto, SP.Brazil.
} 
and SHELTON, 1964; SHELTON and JONES, 1965; JONES, 1966; JONES, 1967; LILLO, 1978). Heath (1980) analyzed larval stages as well as adult specimens of the tiger salamander Ambystoma tigrinum, and all stages developed tachycardia during emersion. As a more complicated pattern, adult Lithobates catesbeianus developed tachycardia when surfacing, whereas this response was absent in the larval form (BURGGREN; MWALUCANA, 1983; WEST; BURGGREN, 1983). Burggren and Doyle (1986 b) also reported that early stages of Lithobates catesbeianus only developed ventilation-heart rate coupling after metamorphosis.

Bradycardia may delay depletion of the intrapulmonary $\mathrm{O}_{2}$ store (JONES and MILSOM, 1982; SHELTON; BOUTILIER, 1982) and, consistently, aquatic hypoxia and hypercarbia reduced diving time in urodeles (Ambystoma tigrinum, Amphiuma tridactylum) and in anurans (Rana temporaria) (JONES, 1966; LUND; DINGLE, 1968; JONES, 1968; JONES, 1972; BURGGREN; DOYLE, 1986 b; LILLO, 1978).

The focus of this study is how diving and surfacing are related to various stimuli. Rana pipiens has external mechanoreceptors at the nares, and these prevent water from entering the buccal cavity during dives. Bilateral section of the ophthalmic nerves of Rana pipiens had no effect on normal ventilation in air, but submergence was associated with an influx of water to the buccal cavity (WEST; JONES, 1976; WEST; VAN VLIET, 1983).

Little information is available for blood pressures and cardiac frequency during artificial ventilation of the lung of diving anurans. Moreover, the information is scarce as to the mechanisms that cause tachycardia upon surfacing.

To address this question applied artificial ventilation with different gas mixtures in a freely diving Lithobates catesbeianus, and cardiovascular reflexes during breathing and diving at were evaluated two temperature $\left(15\right.$ and $\left.25^{\circ} \mathrm{C}\right)$.

\section{MATERIALS AND METHODS}

\section{Animals}

Specimens of Lithobates catesbeianus (mean body weight $0.210 \pm 0.25 \mathrm{~kg}$; mean \pm SEM; n=7) were collected close to Ribeirão Preto, São Paulo, Brazil. They were maintained at the animal holding facility of the Faculty of Medicine of Ribeirão Preto, USP and kept in $1000 \mathrm{~L}$ tanks containing shallow water at $25^{\circ} \mathrm{C}$. Earthworms were provided once a day except for the last $48 \mathrm{~h}$ before experimentation.

\section{Surgical procedure}

The animal was placed into a benzocaine solution $\left(1 \mathrm{~g} \cdot \mathrm{L}^{-1}\right)$ for $10 \mathrm{~min}$, which eliminated 
reflexes, which allowed to catheterize the right femoral artery, using a PE50 catheter (BOUTILIER et al., 1979A). The lung was also catheterized, using a PE90 catheter (For details see GLASS et al., 1978). Both catheters were secured to the skin and incisions were closed using interrupted sutures. The frog recovered in less than $15 \mathrm{~min}$, when placed in benzocaine-free water, after which the animal recovered for $24 \mathrm{~h}$.

\section{Measurements of pulmonary ventilation}

Lung ventilation was measured using pneumotachography for diving animals. The animal was placed into a $10 \mathrm{~L}$ aquarium, where it could respire within an inverted funnel that sealed the airspace by a slight emersion into the water. A Fleisch tube was attached to the neck of the funnel, which allowed measuring respiratory flows according to the Poiseuille principle (Glass et al., 1978). A differential air pressure transducer (Statham 12123) was attached to a multichannel recorder (Narco Biosystems, Inc., Houston TX, USA), and pulmonary ventilation $\left(\mathrm{V}_{\mathrm{E}}\right)$ was continuously recorded along with blood pressures. The arterial catheter was connected to a pressure transducer (COBE Laboratories, Inc., Lakewood CO; USA) (Figure 1).

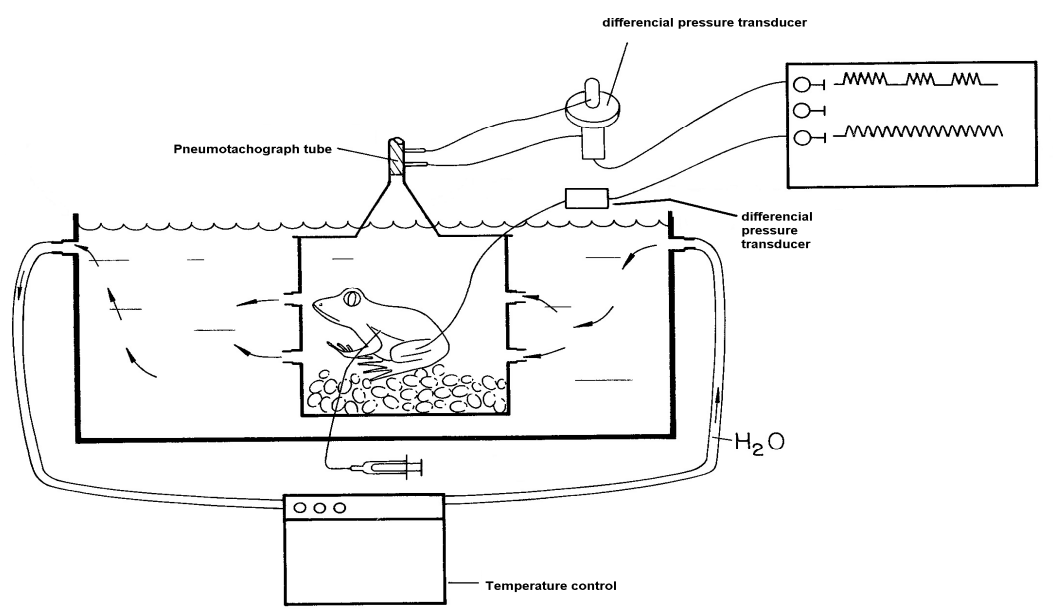

Figura 1: a experimental hydraulic system apparatus permitting voluntaries dives, in normoxic conditions, at $25^{\circ} \mathrm{C}$. The animal was kept in a $7,3 \mathrm{~L}$ receptacle inside of a $30 \mathrm{~L}$ aquarium. The receptacle was equipped with holes in the walls, that permitted the free movement of water, and a funnel-shaped chamber in a surface, open to the air. To monitor pulmonary ventilation, a pneumotachograph tube, was placed onto the outlet of the chamber. the duration of submersions and cardio-respiratory responses (cardiac frequency and blood pressure) in voluntaries dives of Lithobates catesbeianus during artificial lung ventilation, at $15^{\circ} \mathrm{C}$. The artificial lung ventilation was performed during animal dives, using a $20 \mathrm{ml}$ syringe connected with a lung catheter, with a tidal volume of $10 \mathrm{ml} . \mathrm{mim}^{-1}$. Tree gas conditions was used in the artificial lung ventilation, normoxic (atmospheric air), hipoxic (5\% $\mathrm{O}_{2}$ in $\left.\mathrm{N}_{2}\right)$ and hyperoxic $\left(6 \% \mathrm{CO}_{2}\right.$ in air). 


\section{Experimental protocols}

We recorded the duration of dives and lung ventilation, while cardiac frequency $\left(\mathrm{f}_{\mathrm{H}}\right)$ and blood pressures were recorded at $15^{\circ} \mathrm{C}$ or, alternatively, $25^{\circ} \mathrm{C}$. We calculated systolic arterial pressure (Ps) and diastolic arterial pressure (Pd). At $15^{\circ} \mathrm{C}$, the measurements were repeated, but artificial lung ventilation was applied during the dives, using a $20 \mathrm{ml}$ syringe connected to the intrapulmonary catheter Three gas mixtures were used for artificial lung ventilation at 10 $\mathrm{ml} \mathrm{min}{ }^{-1}$ : atmospheric air, hypoxia $\left(5 \% \mathrm{O}_{2}\right.$ in $\left.\mathrm{N}_{2}\right)$ and hypercarbia $\left(6 \% \mathrm{CO}_{2}\right.$ in air).

\section{Statistics}

Statistics was performed using one-way analysis of variance, followed by Bartlett's test for equal variances. With equal variances $(\mathrm{P}<0.05)$ we applied Bonferroni`s multiple comparison test for differences between individual means. Logarithmic transformations were applied in case of unequal variance. If this failed, Friedman's test was applied followed by Dunn's multiple comparison test for differences between means. Values are expressed as mean \pm SEM with significance level $\mathrm{P}<0.05 ; \mathrm{n}=7$.

\section{Results}

The cardiac frequency was significantly different for diving and respiration at the surface $(\mathrm{P}<0.05)$, with $27.1 \pm 2.2$ for breath periods and $19.3 \pm 2.7$ for diving periods at $15^{\circ} \mathrm{C}$, and $47.7 \pm 4.4$ and $35.3 \pm 3.6$ for $25^{\circ} \mathrm{C}$. The cardiac frequency in water at $15^{\circ} \mathrm{C}$ was significantly lower than at $25^{\circ} \mathrm{C}$. The figure 2 illustrates an example of transition from bradycardia to tachycardia when surfacing.

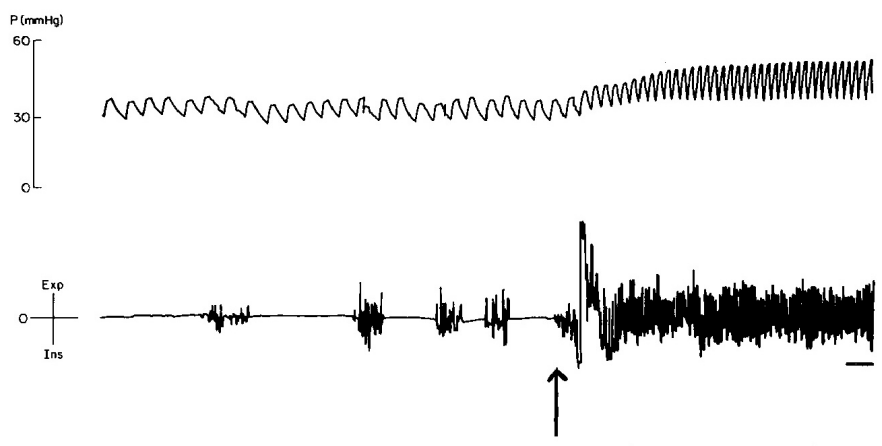

Figura 2: Cardiograph register showing the moment that the animal touch the water surface to ventilate his lungs, with a notable tachycardia. We can note bradycardia in the registers during diving. The arrow show the animal emersion and the right small trace below the register represent the time of 10 seconds. 
Diving significantly reduced Ps and Pd (Pressures during systole and diastole) relative to values during surface ventilation (Table 1).

Table 1. Cardiac frequency during ventilatory periods (VP) and non ventilatory periods (NVP), at $15^{\circ} \mathrm{C}$ and $25^{\circ} \mathrm{C}$.

\begin{tabular}{c|c|c|c}
\hline $\mathrm{f}_{\mathrm{H}}$ & Condition & Temperature & Mean \pm SEM \\
\hline & $\mathrm{VP}$ & $15^{\circ} \mathrm{C}$ & $27.1 \pm 2.2^{+}$ \\
\hline$($ beat/min) & $\mathrm{NVP}$ & $15^{\circ} \mathrm{C}$ & $19.3 \pm 2.7^{*^{+}}$ \\
\hline & $\mathrm{VP}$ & $25^{\circ} \mathrm{C}$ & $47.7 \pm 4.4$ \\
\hline & $\mathrm{NVP}$ & $25^{\circ} \mathrm{C}$ & $35.3 \pm 3.6^{*}$ \\
\hline
\end{tabular}

Mean \pm SEM, $n=7$. * indicate significant difference from PV and + significant difference from $25^{\circ} \mathrm{C}$.

An increase of temperature from 15 to $25^{\circ} \mathrm{C}$ significantly influenced $\mathrm{Pa}$ (Tables 2 and 3) and cardiac frequency in general. Artificial lung ventilation had no significant effect $(\mathrm{P}<$ $0.05)$ on any of the cardiac variables $\left(\mathrm{f}_{\mathrm{H}}, \mathrm{Pa}, \mathrm{Pd}\right)$, and this was independent of the gas mixture applied. (Table 4).

Table 2. Systolic blood pressure during ventilatory periods (VP) and non ventilatory periods (NVP), at $15^{\circ} \mathrm{C}$ and $25^{\circ} \mathrm{C}$.

\begin{tabular}{c|c|c|c}
\hline Ps (mmHg) & Condition & Temperature & Mean \pm SEM \\
\hline & VP & $15^{\circ} \mathrm{C}$ & $39,6 \pm 0,9^{+}$ \\
\hline & NVP & $15^{\circ} \mathrm{C}$ & $36,2 \pm 0,4^{*}$ \\
\hline & VP & $25^{\circ} \mathrm{C}$ & $42,4 \pm 1,0$ \\
\hline & NVP & $25^{\circ} \mathrm{C}$ & $39,8 \pm 0,5^{*}$ \\
\hline
\end{tabular}

Mean \pm SEM, $n=7$. * indicate significant difference from PV and + significant difference from $25^{\circ} \mathrm{C}$. 
Table 3. Diastolic blood pressure during ventilatory periods (VP) and non ventilatory periods (NVP), at $15^{\circ} \mathrm{C}$ and $25^{\circ} \mathrm{C}$.

\begin{tabular}{c|c|c|c}
\hline Pd (mmHg) & Condition & Temperature & Mean \pm SEM \\
\hline & VP & $15^{\circ} \mathrm{C}$ & $32,3 \pm 0,6^{+}$ \\
\hline & NVP & $15^{\circ} \mathrm{C}$ & $29,5 \pm 0,5^{*^{+}}$ \\
\hline & VP & $25^{\circ} \mathrm{C}$ & $35,3 \pm 0,9$ \\
\hline & NVP & $25^{\circ} \mathrm{C}$ & $33,2 \pm 0,6^{*}$ \\
\hline
\end{tabular}

Table 4. Cardiovascular values during artificial ventilatory periods (AVP) and non ventilatory periods $(\mathrm{NVP})$, at $15^{\circ} \mathrm{C}$.

\begin{tabular}{c|c|c|c|c}
\hline & NVP & AVP (AR) & AVP $\left(6 \% \mathrm{CO}_{2}\right)$ & AVP $\left(5 \% \mathrm{O}_{2}\right)$ \\
\hline $\mathrm{F}_{\mathrm{H}}($ beat $/ \mathrm{min})$ & $25,3 \pm 0,6$ & $24,9 \pm 0,6$ & $24,6 \pm 0,7$ & $25,2 \pm 0,1$ \\
\hline $\mathrm{SAP}(\mathrm{mmHg})$ & $44,4 \pm 0,9$ & $43,9 \pm 0,8$ & $43,3 \pm 1,1$ & $44,9 \pm 0,5$ \\
\hline $\mathrm{DAP}(\mathrm{mmHg})$ & $36,6 \pm 0,8$ & $36,4 \pm 0,6$ & $35,7 \pm 0,7$ & $37,1 \pm 0,4$ \\
\hline & & \multicolumn{2}{|l}{} & \\
\hline
\end{tabular}

Mean \pm SEM, $n=7$. * indicate significant difference from PV and + significant difference from $25^{\circ} \mathrm{C}$.

\section{DISCUSSION}

Lithobates catesbeianus confirmed the developed of bradycardia during diving, like showed in the last studies with different species of amphibians. Therefore, the new information from this study is that artificial ventilation of the submerged animal will not elicit any cardio-vascular responses and this is independent of the composition of the intrapulmonary gas. This invites to try to identify a possible stimulus to tachycardia at the surface.

Numerous studies report on increased pulmonary perfusion during lung ventilation and reduced perfusion during breath-holds (SHELTON, 1970, 1976, with Xenopus; Johansen et al.(1970) with Lithobates catesbeianus; West and Burggren (1984); White and Ross (1966) and Wang et al. (2004), with Bufo marinus ). Moreover, diving involves a left-to-right shunt that reduces perfusion of the lung (SHELTON, 1985). In Amphiuma 60\% of the cardiac output perfuse systemic tissues during apnea. Conversely, this percentage was reduced $20 \%$ 
during ventilation of the lung (TOEWS et al., 1971). Lung inflation of Rana temporaria seems to overturn bradycardia (JONES, 1966) and cause pulmonary vasodilatation (EMILIO and SHELTON, 1972).

Our data are, however, consistent with Wang et al. (2004) on decerebrated and unidirectional ventilated Bufo marinus that exhibited small but distinct cardiovascular changes associated with apnea.

Lithobates catesbeianus had no cardiovascular responses to artificial ventilation with gas mixtures. By contrast, Jones (1966) reported tachycardia during forced diving in Bufo bufo, Rana pipiens and Rana temporaria. Anesthetized Bufo arenarum increased $\mathrm{fc}$ and $\mathrm{Pa}$ in response to artificial ventilation. Segura et al., (1981) reported that autonomic blocking combined with removal of bulbo-mesencephalic centers failed to abolish cardiovascular responses to artificial lung ventilation, and they suggested that these reflexes depend on pulmonary receptors. Amphibians inflate the lungs before diving, which motivated (SHELTON; BOUTILIER, 1982) to exclude the hypothesis that the increases of cardiac frequency results from expansion of the lung. Wang et al., (2004) have shown in spite of no statistically significant cardiovascular changes during lung inflation of Bufo marinus, there was a tendency for heart rate, blood pressure and pulmocutaneous flow to be reduced particularly in hypercapnic animal.

Moreover, Johansen et al. (1977) recorded tachycardia during diving of the turtle Pseudemys scripta, exposed to artificial ventilation. Composition of the gas mixture had no specific effects.

There are evidences that chemoreceptor's are involved with these reflex. In Xenopus the lung insuflation with pure oxygen result in higher vasodilatation than atmospheric air, but the last one responded better than nitrogen mixtures (EMILIO; SHELTON, 1972). Studies with Lithobates catesbeianus showed increase in lung perfusion during hypoxic condition in water and the opposite was observed when the animal inspired hypoxic mixture (BOUTILIER et al., 1986). These receptors can be involved within cardiac debt and intracardiac shunt, influence the blood flow resistance in different ways (SHELTON, 1985). Studies with reptiles have shown similar responses, for example in turtle Pseudemys scripta, the spontaneous diving result in bradycardia, reduction of the lung blood flow and increase pulmocutaneous blood flow. The opposite was observed when the turtle came to surface (SHELTON; BURGGREN, 1976; SHELTON; BOUTILIER, 1982). Last studies with this turtle showed that Right-to-Left intracardiac shunt was modulated for vagal eferences (HICKS, 1993; WANG; HICKS, 1996). 
The amphibian lung mechanoreceptors sensitive to $\mathrm{CO}_{2}$ in spite to don't be complete understated, probably are involved in the cardio-respiratory regulation during ventilation (SHELTON, 1970; KUHLMANN; FEDDE, 1979; WEST; BURGGREN, 1983, 1984 ) and byonce of aquatic animals (TAGLIETTI; CASELLA, 1966; EVANS; SHELTON, 1984).

White (1966) suggested that superior centers were involved too in these cardirespiratory reflexes. It has been shown that cardiac vagal motoneurons are located close to the respiratory centers in the medulla of Xenopus (IHMIED; TAYLOR, 1992; WANG et al., 1999a ; 1999b).

Jones (1966) observed the elimination of the tachycardia during the animal surface, after bilateral vagothomy. The same wasn't observed after cut sympathetic heart connections. It suggested that tachycardia during animal surfacing is result to the heart reduction parasympathetic activate, had been proposed by Jones (1966) that lung receptor and baroreceptor were involved in this reflex. The pulmonary vagothomy didn't abolish the cardiac frequency increase associated with lung ventilation in Xenopus laevis (EVANS; SHELTON, 1984), suggesting that stretch receptors don't are totally responsible in cardiorespiratory modulation.

We observed cardiac frequency alteration before the lung ventilation, when Lithobates catesbeianus was moving to surface. Although the artificial lung ventilation during Lithobates catesbeianus diving haven't shown any cardiovascular response, the contact of nares in water surface was immediately followed by significative cardiovascular alterations, with tachycardia and arterial blood pressure increase.

Results obtained from Lithobates catesbeianus after olfactory receptor denervation indicate that tonic stimulation of olfactory receptors by airways $\mathrm{CO}_{2}$ inhibited breathing during hypercarbia (KINKEAD; MILSOM, 1996). These authors suggested that although olfactory and pulmonary receptors feed-back shape the breathing pattern, they were not responsible for initiating or terminating the episodes of breathing.

The cardiovascular responses to touch water surface in Lithobates catesbeianus is similar to trigemio reflex observed in birds and mammals, characterized by bradycardia when animal toch its noise in water (DYKES, 1974; ELSNER et al., 1977; DALY et al., 1979; ECKBERG, et al., 1984). In this reflex, the central cutaneous receptors aferences of trigemio nerve reduce cardiac frequency by vago eferences reflex (ECKBERG et al., 1984).

Dykes (1974) suggested the hypothesis that in mammals, the diving bradycardia was influence by two sensorial ways: stretch lung receptors associated with cutaneous face receptors. Dykes (1974) noted the bradycadia during apnea in seal, similar condition like observed in amphibians patterns respiration. 
Milsom et al. (2004) has been shown in a revised study that there are $\mathrm{CO}_{2} / \mathrm{H}^{+}$sensitive pulmonary receptors (intra pulmonary chemoreceptor's and pulmonary stretch receptors) regulating the breathing patterns in all vertebrates in a manner that reduces dead space ventilation and enhances the efficiencies of $\mathrm{CO}_{2}$ excretion under conditions of environmental hypercarbia and/or reduces de $\mathrm{CO}_{2}$ loss from hyperventilation.

Although more studies are necessary, our studies corroborate with the vision of a complex receptors integration responses during the physiology function of amphibians diving, showing that cardiovascular responses and ventilatory movements are intergraded with environment conditions and animal behaviors, with efficient $\mathrm{O}_{2}$ up take, $\mathrm{CO}_{2}$ elimination and evicting water to get in the lungs.

\section{REFERENCES}

ANDERSEN, H.T. Physiological adaptations in diving vertebrates. Physiol. Rev, v.46, p.212243, 1966.

BOUTILIER, R.G.; GLASS, M.L.; HEISLER, N. The relative distrubution of pulmocutaneous blood flow in Lithobates catesbeianus: Effects of pulmonary or cutaneous hypoxia. J. Exp. Biol, n.126, p.13-39, 1986.

BOUTILIER, R.G. et al. Acid base relationships of the told, Bufo marinus. I. The effects of environmental $\mathrm{CO}_{2}$. J. Exp. Biol. n.82, p. 331-344, 1979 a.

BURGGREN,W.W., DOYLE, M . The action of acetylcholine upon heart rate changes markedly with development in bullfrogs. J. Exp. Zoology, n.240, p.137-140, 1986b.

BURGGREN, W.W.; MWALUCANA, A.Respiration during chronic hypoxia and hyperoxia in larval and adult bulfrogs(Lithobates catesbeianus). I. Morphological responses of the lungs, skin and gills. J.Exp.Biol, n.105, p. 191-203, 1983.

DALY, M.B.; ANGELL-JAMES, J.E.; ELSNER, R. Role of carotid-body chemoreceptors and their reflex interactions in bradycardia and cardiacarrest.The Lancet, n.7, p. 764-767, apr. 1979.

DYKES, R.W. Factors related to the drive reflex in harbor seals: sensory contribuitions from the trigeminal region. Can. J. Physiol. Pharmacol. n.52, p.259-265, 1974.

ECKBERG, D.L.; MOHANTY,S.K.; RACZKOWSKA, M. Trigeminal-baroreceptor reflex interactions modulate human cardiac vagal efferent activity. J. Physiol, n.347, p. 75-83, 1984.

ELSNER, R.; ANGELL-JAMES, J.E.; DALY, M.B (1977). Carotid body chemoreceptor reflexes and their interations in the seal. Am. J. Physiol. v.232, n.5, H517-H525, 1977. 
EMILIO, M.G.; SHELTON, G.. Factors affecting blood flow to the lung in the amphibian, Xenopus laevis. J.Exp. Biol, n.56, p.67-77, 1972.

EVANS, B.K.; SHELTON, G. Ventilation in Xenopus leavis after lung or carotid labyrinth denervation. In: CONGRESS OF COMPARATIVE PHYSIOLOGY AND BIOCHEMESTRY, 1. Proceedings... A75, Liége, Belgium, 1984.

GLASS, M.L.; WOOD, S.C.; JOHANSEN, K. The application of pneumotachography on small unrestrained animals. Comp. Biochem. Physiol, 59A, p. 425-427, 1978.

HEATH, A.G. Cardiac responses of larval and adult tiger salamanders to submergence and emergence. Comp. Biochem. Physiol, v.65(A), p. 439-444, 1980.

HICKS, J.W. Regulation on intracardiac shunting in reptiles : Anatomic VS Effective Shunting. In : the vertebrate gas transport cascade. Adaptations to Environment and Mode of Life (ed. J.E.P.W.Bicudo). 1993. p 252-264,.

IHMIED, Y.M.; TAYLOR, E.W. The topography of the vagal motor column in anaesthetised Xenopus laevis. J.Physiol. v.452. 235p, 1992.

JOHANSEN, K. Air breathing in the teleost. Symbramchus marmoratus. Comp. Biochem. Physiol, v.18, p. 383-395, 1996.

JOHANSEN, K.; BURGGREN,W.W.; GLASS, M.L. Pulmonary stretch receptors regulate heart rate and pulmonary blood flow in the turtle, Pseudemys scripta. Comp. Biochem. Physiol, 58A, p. 185-191, 1977.

JOHANSEN, K; LENFANT, C., ; HANSON, D. Phylogenetic development of pulmonary circulation. Fedn Proc. Fedn Am. Socs Exp. Biol, v.29, p. 1135-1140, 1970.

JONES, D.R. Factors affecting the recovery from diving bradycardia in the frog. J.

Exp. Biol, v.44, p. 397-411, 1966.

JONES, D.R. Oxygen consumption and heart rate of several species of anuran amphibia during submergence. Comp. Biochem. Physiol, v.20, p.691-707, 1967.

JONES, D.R . Specific and sasonal variations in development of diving bradicardia in anuran amphibians. Comp. Biochem. Physiol, n.25, p.821-834, 1968.

JONES, D.R. The effect of thermal acclimation on heart rate and oxygen consumption of frog during submergence. Comp. Biochem. Physiol, v.41, p.97-104, 1972.

JONES, D.R. ; MILSOM,W.K. Peripheral receptors affecting breathing e cardiovascular function in non-mammalian vertebrates. J.Exp. Biol , n.100, p.59-91, 1982.

JONES, D.R.; SHELTON, G. Factors influencing the submergence and heart rate in the frog. J.Exp. Biol, v.41, p. 417-431, 1964.

KINKEAD, R.; MILSOM, W. $\mathrm{CO}_{2}$-sensitive olfatory and pulmonary modulation of episodic breathing in bullfrog. Am. J. physiol. v.270: R134-44, 1996. 
KUHLMANN,W.D.; FEDDE, M.R. Intrapulmonary receptors in the bulfrog: Sensitivity to $\mathrm{CO}_{2}$. J. Comp. Physiol., 132A, p.69-75, 1979.

LILLO, R.S. The effect of arterial-blood $\mathrm{PO}_{2}, \mathrm{PCO}_{2}$ and $\mathrm{pH}$ on diving bradycardia in the bullfrog, Lithobates catesbeianus. Physiol. Zool. v.51, p. 340-346, 1978.

LUND, G.F., ; DINGLE, H. Seasonal temperature influence in vagal control of diving bradycardia in the frog (Rana pipiens). J. Exp. Biol. v.48, p.265-277, 1968.

MILSOM,W.K. et al. Evolutionary trends in airway $\mathrm{CO}_{2} / \mathrm{H}^{+}$chemoreception. Respir. Physiol. Neurobiol. v.144, n.2-3, p.191-202, 2004.

SEGURA, E.T.; BRONSTEIN, A., ; SCHMAJUK, N.A Effect of breathing upon blood pressure and heart rate in the Bufo arenarum. J. Comp. Physiol, v.143, p. 223-227, 1981.

SHELTON, G. The effect of lung ventilation on blood flow to the lungs and body of the amphibian, Xenopus laevis. Resp. Physiol, v.9, p. 183-196, 1970.

SHELTON, G. Gas exchange, pulmonare blood supply, and the partially divided amphibian heart. In: DAVIES, S. (ed.) Perspectives in Experimental Biology. Oxford, New York: Pergamon, 1976. p. 247-259.

SHELTON, G. Functional and evolutionary significance of cardiovascular shunts in the amphibia. In : JOHANSEN, K.; BURGGEN, W.W. (ed.). Cardiovascular shunts. phylogenetic, ontogenetic and clinical aspects. 1985. p 100-116.

SHELTON, G. ; BOUTILIER, R.G. Apnoea in amphibians and reptiles. J. Exp. Biol , v.100, p.245-274, 1982.

SHELTON, G.; BURGGREN,W.W. Cardiovascular dynamics of Chelonia during apnoea and lung ventilation. J. Exp. Biol, v.64, p. 323-343, 1976.

SHELTON, G.; JONES, D.R. Central blood pressure and heart output in surfaced and submerged frogs. J. Exp. Biol, v.42, p.339-357, 1965.

TAGLIETTI,V.; CASELLA, C . Stretch receptors stimulation in frog's lungs. Pflugers Archiv, v.292, p.297-308, 1966.

TOEWS, D.P.; SHELTON, G.; RANDALL, D.J. Gas tensions in the lungs and major blood vessels of the urodele amphibian, Amphiuma tridactylum . J. Exp. Biol, v.55, p. 47-62, 1971.

WANG, T., HICKS, J. Cardiorespiratory synchrony in turtles. J. Exp. Biol, v.199, p. 17911800, 1996.

WANG, T.et al. Control and interaction of the cardiovascular and respiratory systems in anuran amphibians. Comp. Biochem. Physiol. 124A, p. 395-408, 1999a.

WANG, T. et al. Lung inflation reduces fictive ventilation in decerebrated, unidierectionally ventilated and paralysed toads. Resp.Physiol. v.118, p. 181-191, 1999 b.

WANG, T. et al. Interactive effects of mechano- and chemo-receptors inputs on cardiorespiratory outputs in the toad. Respir.Physiol.Neurobiol. v.140, p.63-76, 2004. 
WEST, N.H.; BURGGREN,W.W. Reflex interations between aerial and aquatic gas exchange organs in the larval bullfrog. Am. J. Physiol, v.244, n.6, p. R770-777, 1983.

WEST, N.H.; BURGGREN,W.W. Control of pulmonary and cutaneous blood flow in the toad, Bufo marinus. Am. J. Physiol, v.247, p. R884-R894, 1984.

WEST, N.H., ; JONES, D.R. The initiation of diving apnoea in the frog Rana pipiens. J. Exp. Biol, v.64, p.25-38, 1976.

WEST, N.H.; VAN VLIET, B.N. Open-loop analysis of the pulmocutaneous baroreflex in the frog Bufo marinus. Am. J. Physiol, v.245, p. R642-R650, 1983.

WHITE, F.N.; ROSS, G. Circulatory changes during experimental diving in the turtle. Am. J. Physiol, v.211, p. 15-18, 1966. 